\title{
Remote Sensing Investigation of Geological Hazards in Xingguo County, Jiangxi Province
}

\author{
Min $\mathrm{Yu}^{1,2,3}$, Jiangqin $\mathrm{Chao}^{4}$ \\ ${ }^{1}$ GanZhongNan Institute of Geology and Mineral Exploration, Nanchang, Jiangxi 330000, China \\ ${ }^{2}$ Jiangxi Geo-Engineering (Group) Corporation, Nanchang, Jiangxi 330000, China; \\ ${ }^{3}$ Central South University, Changsha, Hunan 410083, China \\ ${ }^{4}$ Zhaotong University, Zhaotong, Kunming 657000, China
}

\begin{abstract}
Xingguo County is located in the middle and low hilly mountainous areas. The area of the landslide, collapse and debris flow geological disasters is large. The sudden geological disasters such as landslides and mudslides caused by heavy rainfall are increasing year by year. This study mainly used highaltitude aerial imagery $(0.5 \mathrm{~m})$ and Landsat $8 \mathrm{OLI}$ satellite imagery covering Xingguo County as the data source, carried out remote sensing interpretation of geological environment background conditions and geological disasters in the whole area, and carried out on-site verification. At the same time, the correlation between the stratigraphic structure, topography and other factors in the study area and the spatial distribution characteristics of geological disaster points are discussed. The results show that: (1) based on remote sensing image interpretation of 377 geological disaster points; 83 landslide points, 229 hidden danger points, 17 collapse points, 26 hidden danger points, 1 hidden danger point, ground collapse point 1 At 20 places in the geological environment. (2) From the results of remote sensing interpretation, the types of geological disasters in the work area are mainly landslides and landslide hazards (including collapse type), and there are fewer collapses, collapses and debris flow hazards, and most landslide hazard points are unstable. (3) From the distribution of geological disasters, it is mainly within the scope of artificial influence. The construction of excavation slopes on the roads leads to instability of the slopes and induces disasters under the influence of rainfall. In addition, there are a large number of artificial mining mines in the work area. These places are also prone to geological disasters due to unreasonable mining and subsequent prevention and control work. (4) Areas with strong human activities, areas near the fault structure and water system roads are the main influencing factors for geological disasters in the work area.
\end{abstract}

\section{Intorduction}

The application of remote sensing technology in geological disaster investigation has the characteristics of macroscopicity, information richness, multi-temporal phase and dynamic fastness. At present, it has become an important technical means for the 1:50,000 geological disaster investigation. It has obvious advantages compared with conventional methods, and can quickly provide geological environment data and geological disaster distribution maps in the target area ${ }^{[1-5]}$.

Xingguo County is located in the middle and low hilly mountainous areas. The area of the landslide, collapse, and debris flow geological disasters is large. The sudden geological disasters such as landslides and mudslides caused by heavy rainfall are increasing year by year. This study mainly used high-altitude aerial imagery $(0.5 \mathrm{~m})$ and Landsat 8 OLI satellite imagery covering Xingguo County as the data source, carried out remote sensing interpretation of geological environment background conditions and geological disasters in the whole area, and carried out comprehensive research. The research results can provide a scientific basis for the prevention and control of regional geological disasters.

\section{Survey of Research Area}

Xingguo County is located in the south-central part of Jiangxi Province, north of Gangzhou City, and upstream of Pinggu River. It is located in Ningdu County in the east, Yudu County in the southeast, Gan County in the south, Wan'an County in the west, Taihe County in the northwest, Qingyuan District and Yongfeng County in the north of Ji'an City, connecting Jitai Basin, and is under the jurisdiction of Ganzhou City, Jiangxi Province.

Xingguo County is located at the junction of the northeastern end of the Nanling east-west tectonic belt and the Lushan uplift belt. The land area is $3124.46 \mathrm{~km}^{2}$, of which $70.3 \%$ are mountainous, $9.6 \%$ are cultivated land, $7.8 \%$ are waters, and $12.3 \%$ are road manors. Form a natural landscape of "a mountain, a water, a road, a road and a manor".

The county's landforms are mainly low-lying mountains and hills, with a total of north, west and 
southeastern uplifts. The terrain is high, the central part is a basin, and the terrain is low, forming an intermountain basin top that opens to the southwest side with the basin as the center. The lowest point in the south is Longkou Township Village, with an elevation of 127.9m; the highest part in the north is Dawu Mountain in Fengbian Township, with an elevation of $1204 \mathrm{~m}$; the eastern and western mountains are above $1000 \mathrm{~m}$ above sea level.

\section{Remote sensing analysis of geological environment background}

\subsection{Terrain and geomorphology remote sensing interpretation}

According to the geological environment background interpretation elements and absolute elevation, combined with the genetic relationship between geological hazards and geomorphology, the county can be divided into five types of geomorphic units: low-mountain, eroded hills, tectonic denudation hills, tectonic denudation hills, erosion and erosion Karst depressions, erosion and accumulation of alluvial plains in the valley (Figure 1, Table 1).

Table 1. Overview of Xingguo County Topographic and Geomorphic Interpretation Marks.

\begin{tabular}{|c|c|c|c|}
\hline $\begin{array}{c}\text { Topogra- } \\
\text { phical } \\
\text { terrain }\end{array}$ & $\begin{array}{l}\text { Morphological } \\
\text { characteristics }\end{array}$ & $\begin{array}{c}\text { Image } \\
\text { interpretatio } \\
\text { n mark }\end{array}$ & Partition image \\
\hline $\begin{array}{l}\text { Erosion- } \\
\text { dissolving } \\
\text { karst }\end{array}$ & $\begin{array}{l}\text { The bare limestone and } \\
\text { dolomitic limestone in } \\
\text { the interior of the } \\
\text { depression are only } \\
5.69 \mathrm{~km}^{2} \text {. The elevation } \\
\text { of the ground is } 250- \\
360 \mathrm{~m} \text {. There are caves } \\
\text { in the depression, and } \\
\text { spring water is seen in } \\
\text { the eastern part of the } \\
\text { depression. Vegetation } \\
\text { is well developed. }\end{array}$ & $\begin{array}{l}\text { In the OLI } 543 \\
\text { image, this area is } \\
\text { densely red, } \\
\text { showing a deep } \\
\text { red hue, and the } \\
\text { texture is peanut- } \\
\text { shell-like. }\end{array}$ & \\
\hline $\begin{array}{l}\text { Erosion } \\
\text { structure in } \\
\text { low mountain } \\
\text { terrain }\end{array}$ & $\begin{array}{l}\text { The relative height } \\
\text { difference is } 300-800 \mathrm{~m} \text {. } \\
\text { The slope of the slope is } \\
\text { generally } 35-45^{\circ} \text { and } \\
\text { the valley is deep-cut. It } \\
\text { is mostly "V" type. The } \\
\text { base rock at the bottom } \\
\text { of the valley is bare. The } \\
\text { vegetation is below } \\
800 \mathrm{~m} \text {, with bamboo, } \\
\text { pine and cedar as the } \\
\text { mains. The elevation of } \\
800 \mathrm{~m} \text { is mostly thatch } \\
\text { and shrub. The trend of } \\
\text { the mountain range is } \\
\text { northeast, north-north- } \\
\text { east, and basically } \\
\text { coincides with the main } \\
\text { structural line of the } \\
\text { region. The ridge is fish- } \\
\text { ridged, saw-like, and } \\
\text { ridge-like. }\end{array}$ & $\begin{array}{l}\text { In the OLI } 543 \\
\text { image, due to the } \\
\text { dense vegetation, } \\
\text { this area shows a } \\
\text { deep red tone, and } \\
\text { the texture is } \\
\text { characterized by } \\
\text { knife-cut, strip- } \\
\text { like, block-like } \\
\text { shadows. }\end{array}$ & \\
\hline $\begin{array}{l}\text { Tectonic } \\
\text { erosion hilly } \\
\text { terrain }\end{array}$ & $\begin{array}{l}\text { The elevation of the hill } \\
\text { top is greater than } 300 \text { to } \\
\text { less than } 500 \mathrm{~m} \text {, and the } \\
\text { relative } \text { height } \\
\text { difference is } 100-200 \mathrm{~m} \text {. } \\
\text { The slope of the hill top } \\
\text { is generally } 25-35^{\circ} \text {, and } \\
\text { the valley is mostly "U" } \\
\text { type. Very developed, } \\
\text { the vegetation in other } \\
\text { rock distribution areas is } \\
\text { more developed, and the } \\
\text { soil erosion in the } \\
\text { granite distribution area } \\
\text { is more serious. }\end{array}$ & $\begin{array}{l}\text { In the OLI } 543 \\
\text { image, this area } \\
\text { shows a light red } \\
\text { tone, mixed with } \\
\text { light blue-green, } \\
\text { showing more } \\
\text { ridge-like } \\
\text { shadows, and the } \\
\text { vegetation is more } \\
\text { lush. }\end{array}$ & \\
\hline
\end{tabular}
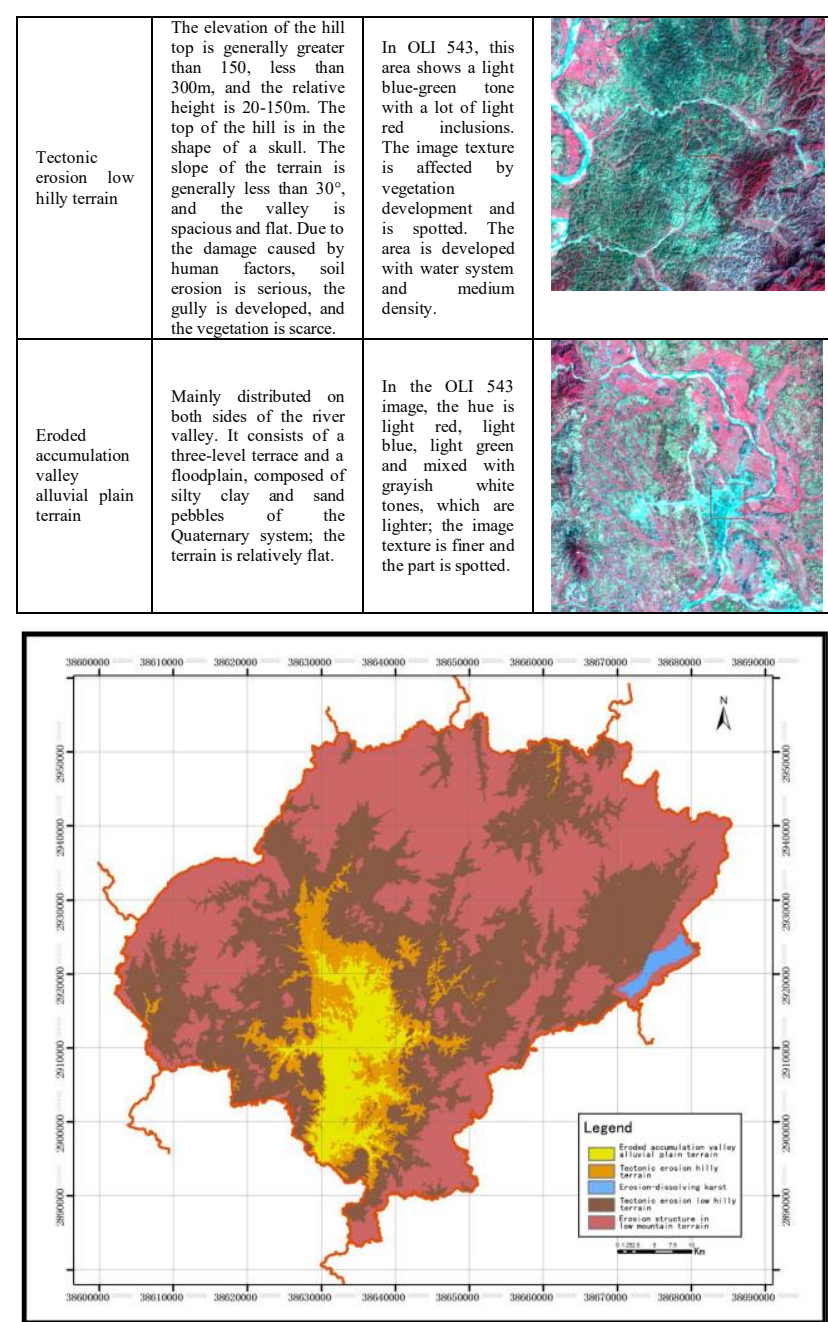

Figure 1. Landform type zoning map of Xingguo County.

According to this remote sensing interpretation, the area of the eroded and accumulated valley plain is $136.97 \mathrm{~km}^{2}$, accounting for $4.26 \%$; the area of the structurally denuded low hilly terrain is $286.50 \mathrm{~km}^{2}$, accounting for $8.91 \%$; the area of the structurally denuded hilly terrain is $845.80 \mathrm{~km}^{2}$, accounting for $26.31 \%$; the area of the low-mountain terrain in the erosive structure is $1927.63 \mathrm{~km}^{2}$, accounting for $59.97 \%$; the area of the erosion-dissolving karst depression is $17.56 \mathrm{~km}^{2}$, accounting for $0.55 \%$. The classification of terrain slope in Xingguo County is shown in Table 2. The terrain slope and slope direction distribution are shown in Figure 2 and Figure 3:

Table 2. Classification of terrain slope in Xingguo County.

\begin{tabular}{cccccc}
\hline Slope & $\mathbf{0}^{\circ}-\mathbf{1 0}$ & $\mathbf{1 0}^{\circ}-\mathbf{2 0}{ }^{\circ}$ & $\mathbf{2 0}^{\circ} \mathbf{- 3 0}$ & $\mathbf{3 0}^{\circ}-\mathbf{4 0}^{\circ}$ & $>\mathbf{4 0}^{\circ}$ \\
\hline & & & & & \\
\hline Area $/ \mathbf{k m}^{2}$ & 1547.78 & 1172.52 & 427.25 & 63.52 & 3.39 \\
$\begin{array}{c}\text { Area share } \\
\text { /\% }\end{array}$ & 48.14 & 36.48 & 13.29 & 1.98 & 0.11 \\
\hline
\end{tabular}




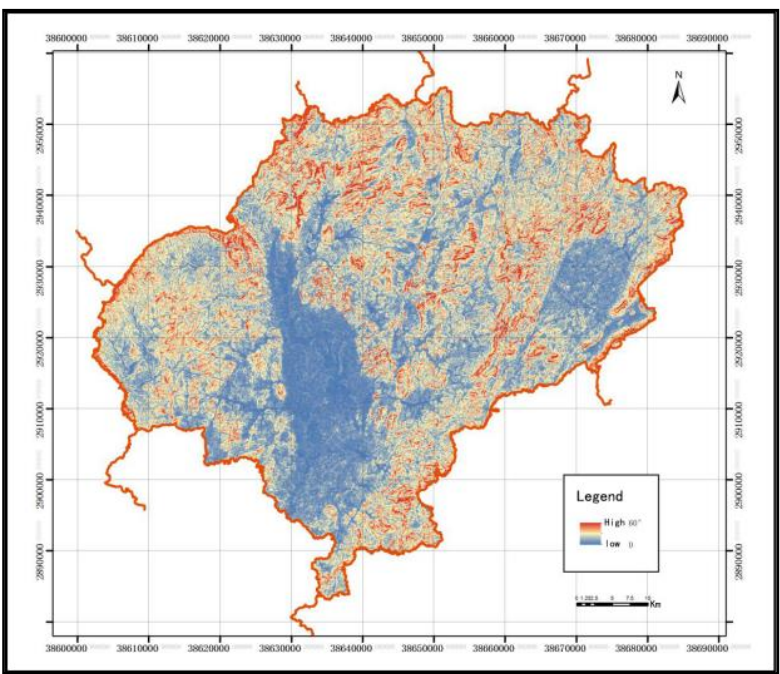

Figure 2. Terrain slope distribution map of Xingguo County.

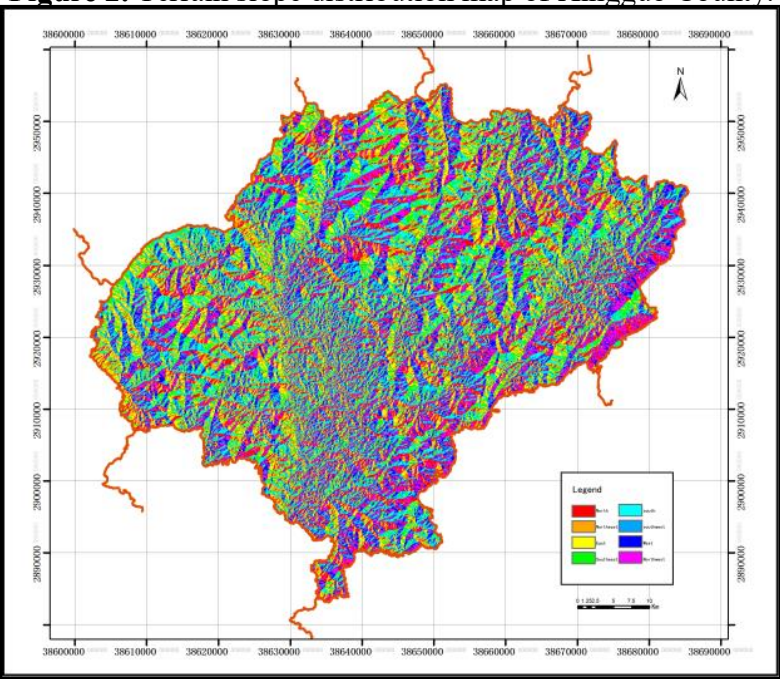

Figure 3. Terrain slope direction map of Xingguo County.

\subsection{Remote sensing interpretation of geological structures}

Xingguo County is located at the junction of the northeastern end of the Nanling East-West tectonic belt and the Lushan uplift belt, and undergoes multiple periods of tectonic activity. The structural traces are mainly wrinkles and fractures. Xingguo County has experienced a multi-period tectonic movement. According to the linear characteristics of the development direction, distribution form and mutual relationship of each tectonic trace on the remote sensing image, the interpretation of the geological structure information in the working area is shown in Fig. 4.

The linear fault structure of the working area is wavy, straight, curved and jagged. These linear fault structures with a certain scale constitute the structural pattern of the area. According to the linear structure image features displayed by remote sensing images, the main structures in this area are divided into two levels according to their spatial distribution direction, size, depth of cut, degree of solvability, control of magmatism and sedimentation. Among them, the thick and long linear structure is a deeper fractured structural belt, which is a reflection of the deep fault structure. The area is divided into main (I- level) linear fault structures; the remote sensing image features obvious information, forming a series of Linear negative terrain, medium and small linear structures are divided into secondary (II-level) linear fracture structures. According to the linear structure classification requirements of remote sensing, the linear structure in the area is divided into 38 main (I-level) linear fault structures and 75 secondary (II-level) linear fault structures.

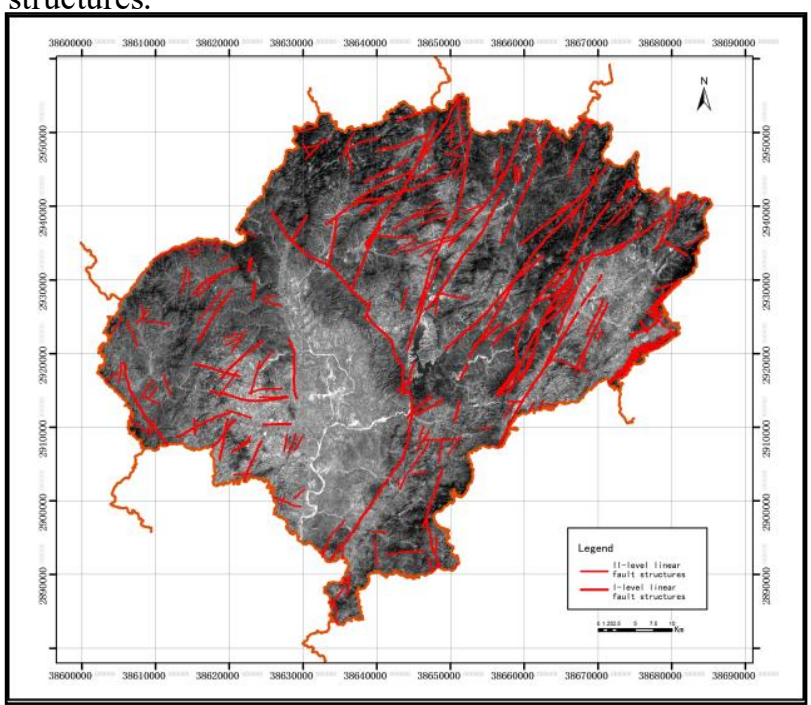

Figure 4. Remote Sensing Linear Structure Interpretation map of Xingguo County.

\section{Remote sensing interpretation and comprehensive analysis of geological disasters}

This work uses SWDC high-altitude aerial image as the main information source, with a spatial resolution of 0.5 $\mathrm{m}$. After interpretation, the scale of geological disasters in Xingguo County is mainly small, with 377 geological disaster points and 83 landslide points. At point 229, at the collapse point 17 , there are 26 hidden danger points, 1 hidden point of debris flow, 1 ground collapse point, and 20 geological environment points (Figure 5, Table 3)

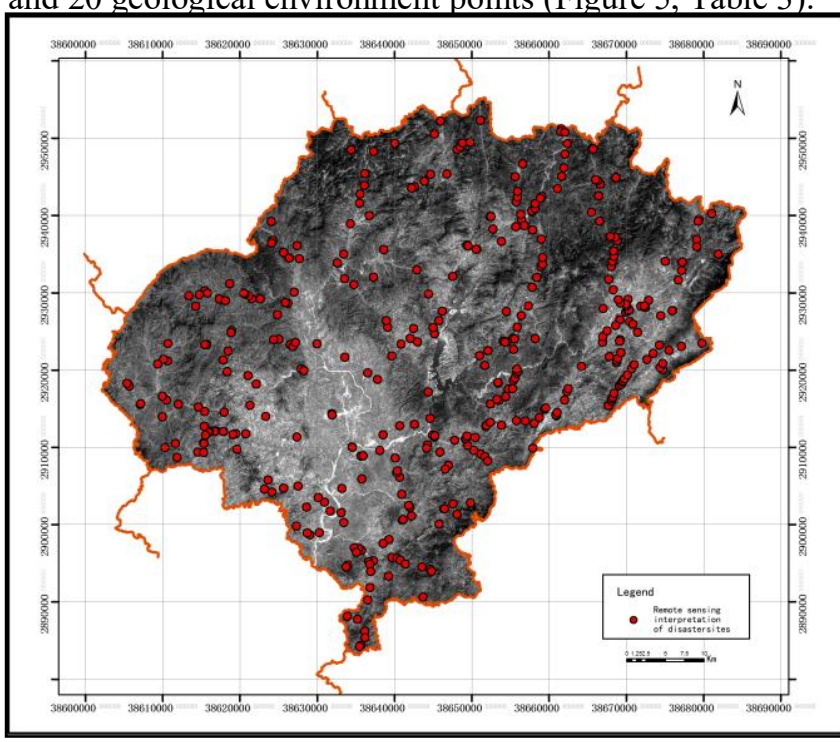

Figure 5. Distribution of geological disasters in remote sensing interpretation in Xingguo County. 
Table 3. Comparison of remote sensing interpretation geological disaster points and field verification results in Xingguo County.

\begin{tabular}{|c|c|c|}
\hline $\begin{array}{c}\text { Type of } \\
\text { geological } \\
\text { disaster }\end{array}$ & Remote sensing image & Field verification result \\
\hline landslide & & \\
\hline
\end{tabular}

\section{Conclusion}

(1) Interpretation of 377 geological hazard points based on remote sensing images; 83 landslide points, 229 hidden danger points, 17 collapse points, 26 hidden danger points, 1 hidden point of debris flow, 1 ground collapse point, geological environment Point 20.

(2) From the results of remote sensing interpretation, the types of geological disasters in the work area are mainly landslides and landslide hazards (including collapse type), and there are fewer collapses, collapses and debris flow hazards, and most landslide hazard points are unstable.

(3) From the distribution of geological disasters, it is mainly within the scope of artificial influence. The construction of excavation slopes on the roads leads to instability of the slopes and induces disasters under the influence of rainfall. In addition, there are a large number of artificial mining mines in the work area. These places are also prone to geological disasters due to unreasonable mining and subsequent prevention and control work.

(4) Areas with strong human activities, areas near the fault structure and water system roads are the main influencing factors for geological disasters in the work area.

\section{References}

1. Gatelli F, Guarnieri A M, Parizzi F, et al. Use of the spectral shift inSAR interferometry: Applications to ERS-1[C]. Hamburg: SecondERS-1 Symposium, 1993.

2. Gabriel A K, Goldstein R M. Crossed orbit interferometry: Theory andexperimental results from SIR-B [J]. International Journal of RemoteSensing, 1988, 9(5): $857-872$.

3. KEEFER D V. Statistical analysis of an earthquakeinduced landslide distribution-the 1989 Lom a Prieta, California event[J]. Engineering Geology, 2000, 58(3/4): 231-249.

4. JIBSON $\mathrm{R} \mathrm{W}$, HARP E L, MICHAEL J A. A method for producing digital probabilistic seismic landslide hazard maps[J]. Engineering Geology, 2000, 58(3/4): 271-289.

5. CAMPBELL $\mathrm{K} \quad \mathrm{W}$. Empirical near-source attenuation relationships for horizontal and vertical components of peak ground acceleration. peak ground velocity, and pseudo-absolute acceleration response spectra[J]. Seismological Research Letters, 1997, 68(1): 154-179. 